\title{
TABU E PODER POLÍTICO: UM ESTUDO DA INTERDIÇÃO FEMININA NA TRADIÇÃO RELIGIOSA AFRO-PARAENSE MINA NAGÔ
}

\author{
Lucielma Lobato SILVA ${ }^{1}$ \\ SEDUC/PA \\ lucielmalobato@hotmail.com
}

Resumo: Muito já foi estudado pela Historiografia e pela Antropologia afroreligiosa a respeito do importante papel exercido pelo gênero feminino, em que este gênero pode, em igual patamar que seu sexo oposto, administrar os espaços sagrados como sacerdotes ou sacerdotisas (SILVA, 2009). Por outro lado, na religião Mina Nagô, tradição afro-paraense, é criado, em seus intramuros, o tabu menstrual, em que a mulher é interditada durante este período. Dessa forma, este artigo busca analisar este tabu em casas de santo de Mina Nagô, do município de Abaetetuba-PA, onde este elemento simbólico é ultrapassado para o social (DOUGLAS, 2010) e se torna um importante meio de interdito do feminino, o qual fica restrito às funções políticas e administrativas, durante este período. Assim, o tabu menstrual tem a função de diminuir ou abafar o poder político do feminino no interior da referida religião em que a mulher também pode ser o importante pilar.

Palavras-Chave: Gênero. Tabu Menstrual. Poder Político.

Abstract: Much has been studied for history and anthropology africanreligious about the important role played by women, where it can on equal footing with their opposite sex administer the sacred spaces as priests or priestesses (SILVA 2009). On the other hand, Religion in Mina Nago tradition africanPara, is created on the intramural their menstrual taboo, where women are banned during this period. Therefore, this article seeks to analyze this taboo

\footnotetext{
${ }^{1}$ Graduada no curso de Licenciatura e Bacharelado em História pela Universidade Federal do Pará (UFPA/2009), Especialista em Educação para Relações Etnicorraciais pelo Instituto Federal de Educação, Ciência e Tecnologia do Pará (IFPA/2011). Mestra em Ciências da Religião pela Universidade do Estado do Pará (UEPA/2011). Atualmente dedica-se ao estudo da religião de tradição afroparaense Mina Nagô, gênero e poder. Professora efetiva da Secretaria de Estado de Educação do Pará, trabalhando com a disciplina História. Tem experiência na área de História. Atuando principalmente nos seguintes temas: cultura, religiosidade, gênero e religião afro-brasielira.
} 
in houses of the holy city of Mina NagoAbaetetuba-PA, where this symbolic element is passed to the social (DOUGLAS, 2010), and is an important means of forbidden female, which is restricted political and administrative functions during this period. Thus, the menstrual taboo serves to lessen or muffle the political power of women within the religion that the woman can also be an important pillar.

Keywords: Gender. Menstrual Taboo. Political Power.

\section{Introdução}

O tabu é o guardião do espaço do poder [...] Poder mágico implica também poder político. E, sob esse prisma, o tabu ganha novo colorido (AUGRAS, 1989, p. 45).

A relação entre religião e política é muito tensa, apesar de ambas estarem filiadas e caminharem em pares bastante unidos. A combinação da política como aparelho de dominação do Estado e religião Mina Nagô não é algo comum no município de Abaetetuba$\mathrm{PA}$, ambas estão separadas, não se vê nenhum indivíduo desta religião ocupando cargos públicos, apesar de os integrantes religiosos estarem presentes no interior dos diversos partidos políticos.

Por outro lado, a tradição religiosa afro-paraense Mina Nagô é substancial no que concerne ao poder político em seu interior, uma vez que este é demarcado pela intensa formulação de tabus restritivos. Augras (1989) salienta que o tabu é um importante mecanismo de manutenção da ordem política e social, já que ao serem criados há a forte incumbência mental de que se o individuo transgredir a regra, imenso será seu prejuízo. Vários são os tabus que estão presentes na religião Mina Nagô, mas o hierárquico e o menstrual é quem vão nortear este estudo.

O tabu é revertido por um papel primordial na interdição do gênero feminino, o qual apesar de estar presente como o comando religioso, isto é, sacerdotisa/mãe de santo, ou como filha de santo ou ainda como participante e adepta da religião (SILVA, 2009), ainda 
assim é afastado de seu poder religioso e político no intramuros dos terreiros, pois "uma mulher menstruada não pode entrar na casa de santo, não pode tocar em instrumentos ou objetos sagrados e nem em seus pais de santo" 2 .

Isso denota que a mulher, apesar de ser importante nas religiões afro-brasileiras, mesmo assim o patriarcalismo social se transfere da sociedade para tais religiões e, em especial, à Mina Nagô. E, de maneira velada, consegue interditar o gênero feminino devido à sua condição biológica, que lhe é própria e incontrolável (DOUGLAS, 2010). Dessa forma, este trabalho tem por objetivo analisar o tabu menstrual como um importante meio de controle político em que a mulher não controla, mas é controlada, mesmo quando detém o poder do sagrado. Isso porque a menstruação é fonte potencial de perigo e poder.

Souza (2011) assinala que estudar religião e gênero é uma combinação duas vezes marginal, primeiro o é para a academia, e segundo, para a religião, que em sua maioria são excludentes, quando se pensa nas posições do feminino. Por isso, este estudo ratifica sua importância, pois na religião Mina Nagô as mulheres são muito importantes, é o mesmo lócus onde estas são segregadas, pelo menos nos períodos de fluxo do sangue menstrual. Como metodologia da pesquisa, foi utilizada pesquisa de campo e bibliográfica com abordagem qualitativa e modelo de investigação etnográfico/ participativo (SEVERIO, 2009; TRIVIÑOS, 1987).

Assim, este trabalho apresenta primeiramente o Tabu e poder político, em que é analisada a formulação das restrições dos tabus como importante meio para a detenção e o controle do poder religioso, o qual no intramuros da Mina Nagô é reelaborado como poder político. Em seguida, será demonstrado $O$ tabu menstrual: Importante mecanismo de interdição do feminino na religião Mina Nagô; e nesse momento será abordado o tabu como forte meio de controle

\footnotetext{
${ }^{2}$ Entrevista no Centro de Manifestações Mediúnicas Oshalufã, com o sacerdote Daniel de Oshalufã, no dia 15/05/2011.
} 


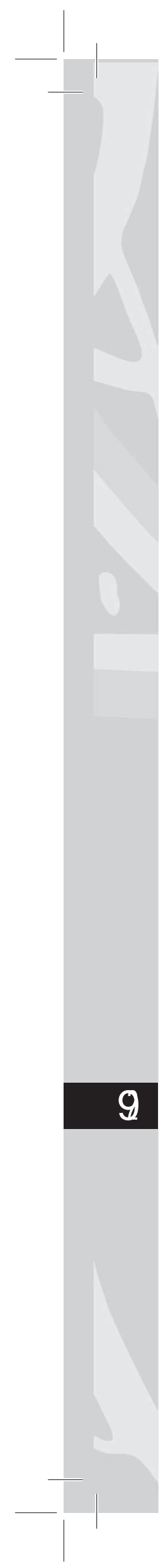

e interdição do gênero feminino, mesmo quando esta é dona do espaço sagrado. E, por último, $A$ menstruação: como poder feminino na religião Mina Nagô, em que se afirma que a menstruação é na verdade um elemento que emana poder, pois uma mulher menstruada tem seu poder multiplicado, e por isso é abafada, interditada por seu sexo oposto, devido ao temor à menstruação, pois é um momento em que a mulher é comparada à natureza, por estar mais perto das funções dos animais (SARDENBERG, 1994).

\section{Tabu e poder político}

A palavra tabu tem seu significado totalmente marcado ou ainda discriminado por ser algo proibido em razão de possuir poder que se estabelece em certos casos no sagrado, e por isso se torna perigoso e proibido. É por essa razão que os conceitos de sagrado, perigoso e proibido estão estritamente conectados (TEDLOCK, 2008). Para Freud (1950) em sua importante obra Totem e Tabu: O significado de 'tabu', diverge em dois sentidos contrários. Para nós significa, por um lado, 'sagrado', 'consagrado', e, por outro, 'misterioso', 'perigoso', 'proibido', 'impuro' (FREUD, 1950, p. 18).

Porém o tabu não designa apenas o caráter de sagrado/ perigoso, de uma pessoa ou de uma coisa, mas também os dispositivos montados para lidar com ele, apontando para a presença do dito poder e para a dimensão da realidade a qual este está engajado (AUGRAS, 1989). Estes dispositivos, por sua vez, são organizados pelos homens, dentro de religiões ou no cerne da sociedade para controlar outros homens e a eles próprios. Nesse sentido, o tabu permite lidar com o poder sem risco de destruição, mas demonstrando a realidade por meio das interdições.

O poder dessa dita realidade, ao emitir ameaça aos que detêm o controle social, político, religioso ou econômico, no sentido de uma possível perda de hierarquia, torna-se alvo da criação (pelos controladores da sociedade) das teses "tabulisticas", ou seja, da formulação de diversos tabus restritivos para abafar o poder dos 
"marginais", isto é, dos que estão à margem, os quais poderiam inclusive substituí-los no comando da sociedade, uma vez que detêm o dito poder.

Nessa perspectiva, o tabu ganha uma face de ambiguidade por lidar com contradições e estranhezas, pois o perigo, segundo Douglas (2010), marca justamente o estado de transição de pessoas ou coisas (objetos, comidas, animais, vegetais etc.) que não estão em um estado anterior e nem no seguinte, é algo indefinível.

A isso Turner (1974) denomina liminaridade, ou ainda fase liminar, que, segundo o autor, é a fase intermediaria entre o distanciamento e a reaproximação, em que as características do indivíduo que está transitando são ambíguas, misturando sagrado e profano, por exemplo, (ELIADE, 1992). Turner demonstra a existência de espaços bem definidos de sagrado e profano, em que os ritos de passagem se dão com uma simples ida para o estado sagrado $\mathrm{e}$, posteriormente, com a volta ao estado profano original.

Nas religiões afro-brasileiras, o tabu se faz fortemente presente em diversas categorias religiosas e, principalmente, nas mitologias, uma vez que vários são os deuses que possuem quizilas ${ }^{3} \mathrm{com}$ outros deuses, e, por essa razão, não podem manter muito contato. Um exemplo claro é demonstrado entre os filhos de Iansã, a deusa da tempestade, que tem quizila com Oxum, pois ambas são esposas de Xangô; e assim os filhos de ambas têm geralmente problemas de relacionamento; além disso, os tabus alimentares são frequentes: um indivíduo filho de Oxalá, por exemplo, um dos principais orixás do panteão afro, não pode, de forma alguma, comer caramujo, pois o mito diz que, quando Oxalá foi jogado no rio, o caramujo o matou, assim, cada orixá tem suas proibições especificas (AUGRAS, 1989).

$\mathrm{Na}$ tradição religiosa afro-paraense Mina Nagô, a construção do tabu se reverte como um importante mecanismo de controle social, em que um iniciado não pode, de forma alguma, arriscar as normas do tabu e transgredi-lo, pois sabe que se assim o fizer grande

${ }^{3}$ Tabus na linguagem afro-brasileira (AUGRAS, 1989). 
será o seu prejuízo, sob a pena de levá-lo à morte ou de passarem por muito sofrimento físico ou mental. Assim, esse indivíduo permanece no seu devido lugar, sem grandes questionamentos, pois sabe que o tabu é muito mais do que uma simples regra ou lei, é uma proibição simbólico/ritual; ele tem um caráter de proteção contra o perigo que este ser está exposto se transgredir a ordem. Essa proteção é feita pelos sacerdotes devidamente responsáveis pelo sagrado, que darão o amparo a seus iniciados, uma vez que se dirigir ao sagrado emana um sério perigo e somente um conhecedor nato pode realizar tal proeza. Desse modo, segundo Augras (1989):

O povo, por sua vez, é fortalecido na convicção de que os tabus constituem eficaz dispositivo de proteção contra todos aqueles que detêm o dúbio privilégio de relacionar-se diretamente com os poderes sobrenaturais [...]. No fim das contas, os tabus, constituem a garantia de que o mundo é mesmo como dizem os que detêm a exclusividade do acesso ao poder: há seres e coisas das quais é proibido aproximar-se (AUGRAS, 1989, p. 47).

Dessa maneira, somente um sacerdote pode realizar certos rituais, uma vez que, se um iniciado ou leigo o fizer, as penas a serem pagas são de um preço altíssimo; é o que o povo de santo chama de "peia", momento em que as entidades castigam o ser que transgrediu a ordem ou o tabu pré-estabelecido. Tal situação é exemplificada na fala de Leonardo de Ogum ${ }^{4}$, o qual explica o caso de um determinado filho de santo de sua casa, o qual é seu irmão de santo, que esteve enfrentando "peia de santo":

Bom o Y está na "peia", isso por que ele resolveu realizar trabalho (ritual) de grande complexidade na porta do cemitério [...]. Só que este tipo de atividade só

\footnotetext{
${ }^{4}$ Filho de santo do Centro de Manifestações Mediúnicas Oshalufã, situado no município de Abaetetuba e tem como sacerdote Daniel de Oxalufã.
} 
pode ser feita pelo pai de santo da nossa casa não por ele que é um mero iniciado [...], que ainda não conhece nada, isso é um desrespeito a hierarquia religiosa, não se pode passar na frente do pai de santo [...]. Isso não poderia ser feito [...] É por isso que o Y está na "peia", você viu até mãe dele já desencarnou (morreu), o pai de santo acredita que não tem haver com o desrespeito, mas seu Zé Pelintra já disse a próxima será pior, e eu acredito que o desrespeito contribuiu para a morte (grifo meu $)^{5}$.

Outro caso que demonstra a maneira pela qual o tabu passa a ser um forte controle social, é que na casa de Pai Paulo de Iansã, um filho de santo $\mathrm{X}$, resolveu cortar os animais para seu orixá sem os devidos consentimento ou conselhos de seu pai de santo, pois resolveu adentrar à magia negra:

A minha filha a coisa é seria. O X não poderia realizar
trabalho do jeito que fazia sem a minha permissão [...]
nós das religiões afro primamos justamente a hierarquia,
o respeito pela hierarquia, você vê que até as entidades
têm hierarquia, e esse tipo de desobediência me afeta,
mas afeta principalmente as entidades que não aceitam
e passam a maliná-lo. Veja como ele está [...] está com
problemas mentais [...] dizem que é depressão, mas na
verdade isso é quizila das próprias entidades dele [...].

O tabu como controle social é introjetado entre os filhos de santo, isso pode ser visto na fala Mãe Bena de Yemanjá, onde ela relata o mesmo caso acima:

Olha o X sabia dos perigos que é mexer com esse tipo de coisa que ele estava mexendo (magia negra), o nosso

\footnotetext{
${ }^{5}$ Entrevista com Leonardo de Ogum, filho de santo do Centro de Manifestações mediúnicas Oshalufãno dia 07/07/2011.

${ }^{6}$ Entrevista com o Sacerdote Paulo de Iansã, zelador do Templo Cristão Afro de Nagô Oxóssi Urucáia, situado em Abaetetuba-PA, no dia 15/08/2008.
} 
pai não nos ensinou isso! Ai ele agora está assim [...] com problemas mentais, dizem que é depressão. Mas na verdade ele ficou louco, sente fortes dores de cabeça e quando dói muito ele bate a cabeça bate na parede [...]. Isso é peia de santo, é claro! Ninguém deve desobedecer a hierarquia! Acredito que ele não demora muito a desencarnar (morrer). ${ }^{7}$

Além dos tabus de interdição por hierarquia religiosa, há na Mina Nagô, e em muitas tradições afro-religiosas, um importante tabu ligado ao ciclo biológico feminino, isto é, a menstruação, que, por ser algo incontrolável e estar no nível de liminaridade, passa a ser revertido de perigo, pois segundo o Sacerdote Daniel de Oshalufã "uma mulher menstruada não pode nem entrar na minha casa, [...] e mais, uma filha de santo em plena consciência não deve se quer se aproximar de mim". Dessa maneira, esta mulher passa a ser um ser interditado diante do poder político, principalmente no período de seu fluxo menstrual.

A menstruação para Mãe Maria José não é tabu, porém é um período de restrição às demais filhas de santo quando menstruadas, uma vez que segundo ela é necessário saber lidar com esse sangue, uma vez que ele emana uma explosão de energia que uma simples iniciada não sabe lidar, e por essa razão ela é interditada, e nas suas próprias palavras:

Durante as 24 horas do inicio da menstruação os médiuns não podem vir na casa e não podem tocar em nada, se vierem não podem se envolver na corrente tem que ficar do lado de fora da corrente, porque o sangue atrai muitos espíritos para a casa, muitas más influências para a casa, e quando um médium está menstruado dentro da corrente esta fica pesada

\footnotetext{
${ }^{7}$ Entrevista com Mãe Bena de Yemanja, filha de santo do Templo Cristão Afro de Nagô Oxóssi Urucáia, situado em Abaetetuba-PA, no dia 20/08/2008.

${ }^{8}$ Entrevista com Sacerdote Daniel de Oshalufã, zelador do Centro de Manifestações Mediúnicas Oshalufã, no dia 02/07/2011.
} 
[...] Bom, mas há casos e comigo já aconteceu de um inicio de trabalho, e um trabalho muito importante a menstruação descer [...], então a entidade segura o fluxo, parando ofluxo, e quando terminava o ritual a menstruação voltava [...]." (meu grifo)

Assim, a construção dos tabus nas religiões afro-brasileiras, e em especial na Mina Nagô, é demarcada por um forte princípio moral e hierárquico, em que, na verdade, demarca a quem pode ser reservado o poder político-ritual. Essa situação ratifica e conserva o poder do sagrado, que fica centralizado nas mãos dos sacerdotes e sacerdotisas, os quais, munidos do sagrado, controlam o poder político nos intramuros dos templos ou terreiros de Mina Nagô. Então, um filho de santo recém-iniciado na religião e mulheres passíveis à menstruação vivem à margem do processo políticoreligioso.

\section{O tabu menstrual: importante mecanismo de interdição do feminino na religião Mina Nagô}

Em várias sociedades, a menstruação é construída, segundo Douglas (2010), sob forte elaboração simbólica. Em algumas, o sangue é tido como causador de nojo, aversão e horror, nas quais, para uma mulher menstruada, significa extrema vergonha. Essa construção social da menstruação lança seus raios para o plano do simbólico, agindo então como um forte elemento poluidor, dotado de impurezas, o qual tem função de gerar o mal aos que estão em redor. Por essa razão, a simples presença de uma mulher menstruada denota perigo em potencial. Na religião Mina Nagô esse perigo fica claro, quando Mãe Silvia afirma: "Na nossa religião o sangue menstrual é um sério problema! Ele pode acabar com a força da entidade, pode

\footnotetext{
${ }^{9}$ Entrevista na Tendo Espírita de Oxum, com a sacerdotisa Mãe Maria José, no dia $29 / 05 / 2011$
} 
acabar com ritual! Não uma filha de santo menstruada só prejudica, ela nessa condição não deve nem vir na casa!"10

E dessa forma, elas (as mulheres menstruadas) devem ser afastadas da sociedade quando tomadas por seus fluxos biológicos, por acreditarem que sua presença pode ser maléfica e perigosa. Esse tabu esteve presente, de acordo com Sardenberg (1994) ${ }^{11}$, desde as sociedades ditas primitivas até hoje, como entre os judeus ortodoxos, em diversos níveis: o afastamento, a interdição alimentar e sexual, interdição às tarefas ritualísticas e de trabalho no seio da comunidade.

Para Douglas (2010), o tabu da menstruação nas sociedades primitivas é sedimentado a partir da:

Crença que, sem uma contra magia apropriada, o contacto com o sangue de uma mulher menstruada adoenta o homem, provoca-lhe vômitos prolongados, "mata", o seu sangue de tal maneira que este enegrece e corrompe os seus sucos vitais. A sua pele ensombra-se, amolece e engelha-se à medida que a carne definha. Tal contacto entorpece irremediavelmente o seu entendimento e traduz-se mais cedo ou mais tarde por um lento declínio e pela morte. (DOUGLAS, 2010, p. 108).

Esse mesmo tabu foi também visualizado pela antropóloga paraense Angélica Maués (1993), em Itapuá, uma comunidade de pescadores situada no município de Vigia, onde este tabu se eleva do natural (biológico) para o social (simbólico), fazendo com que o gênero feminino seja excluído de diversas funções, o que é justificado pela sociedade itapuense como algo normal, pois a mulher menstruada é, de acordo com informações de pessoas da comunidade, instrumento de impureza, poluição e veneno que, em

\footnotetext{
${ }^{10}$ Entrevista no Terreiro da Cabocla Mariana de Mina Nagô, com a sacerdotisa Mãe Silvia, no dia 20/07/2011.

${ }^{11}$ SARDENBERG, Cecília M. B. De sangrias, tabus e poderes: A menstruação em uma perspectiva sócio-antropológica. Rio de Janeiro. Estudos Feministas, n. 2, 1994.
} 
contato com os outros seres (homem), pode ser o fator de panema (azar). Tal condição, na análise da autora, ratifica o status de sujeição feminino em Itapuá. E nas palavras de Angélica Maués (1993):

A mulher, particularmente, por sua especificidade $e$ ambiguidade em poder mover-se continuamente entre dois dominios distintos, o da cultura e o da natureza, a ocupação social que ela ocupa, reflete exatamente esse modo de perceber as coisas. Ela se difere ou se opõe ao homem pela sua participação em processos naturais que impedem de uma interferência social direta, uma vez que eles não podem ser controlados por influencia humana. Como esse controle rigoroso não pode ser feito, entra em jogo, então os artifícios criados pela própria sociedade que, através das regras culturais em vigor para essa situação, realiza uma interferência que de outro modo não é possível conseguir. (MOTTA, 1993, p. 103).

Dessa maneira, Maués (1993) afirma que o ciclo biológico feminino em Itapuá é o forte elemento que restringe o feminino de atuar em diversas funções sociais, culturais e rituais. $O$ mais impressionante é que essa situação é ratificada por elas mesmas (mulheres itapuenses) como algo absolutamente normal, pois nesse período poderiam causar o mal a todos os que as rodeiam, e, em especial, o seu sexo oposto; é por essa razão que estas mulheres devem ser afastadas. É nessa perspectiva que Frazer (1950) firma que se um negro australiano, descobrir que sua mulher menstruada deita em sua esteira, pode até matá-la, e assim, é necessário afastar a mulher pelo perigo "vermelho".

Segundo Augras (1989), o ato de afastar o feminino ainda se vê na sociedade brasileira, quando do chamado resguardo alimentício que é transpassado para o momento em que o fluxo menstrual está presente, é o período em que não se pode comer:

comida temperada, couve ou repolho, porque são verduras carregadas, que causam dores e inflamações.

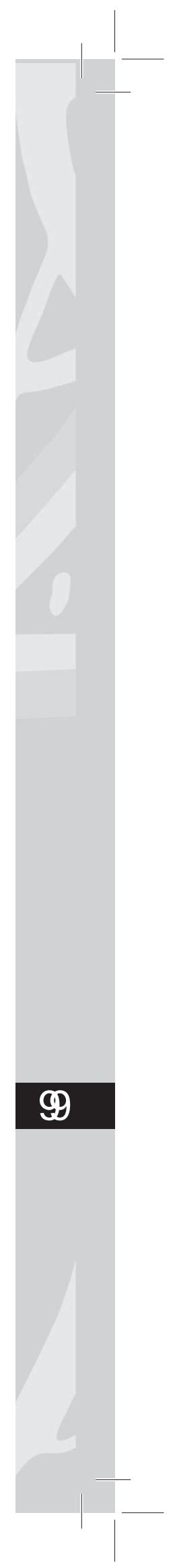


Quiabo faz com que o menstruo fique escorregadio, viscoso. Batata doce e ovo tornam o fluxo catamenial fedorento. Jerimum também não é bom. (AUGRAS, 1989, p. 19).

Essas restrições são importantes para que a mulher não seja perigosa a ela mesma e aos outros. Uma mulher se torna perigosa a ela mesma "quando resolve ir para a guma menstruada, porque as entidades malinam, [...] machucam. Aí fica difícil porque esse ato só faz mal a ela mesma, se de repente resolver ir no trabalho nesse estado." 12

De acordo com a tradição brasileira, uma mulher, quando menstruada, não pode passar por cima de uma espingarda ou de qualquer instrumento de um caçador, pois jamais funcionará; não pode igualmente passar em cima de redes de pesca, pois estas jamais apanharão peixes, pois estará panemada. Também não pode pegar o leite fresco, porque este se tornará azedo. (AUGRAS, 1989; MAUÉS, 1993). Essas restrições ou tabus são responsáveis pelo afastamento do gênero feminino do convívio social e das determinações políticas. Assim, Mãe Raimundinha de Ogum menciona: "Uma filha de santo quando menstruada, não pode tocar em nada, não toca no tambor, não entra no roncó (quarto sagrado), não entra na casinhola do exu, se de repente precisar de algo do roncó deve pedir a alguém que não esteja impuro!" 13

Assim, o interdito do feminino, devido ao seu ciclo biológico, não é verificado apenas em sociedades patriarcais, no interior das religiões afro-brasileiras, e no tocante à Mina Nagô, em que a participação e a administração do posto sacerdotal são tarefas de ambos os sexos, já que mulheres e homens podem receber entidades, bem como se tornarem donos dos espaços sagrados, isto é, pais ou mães de santo (SILVA, 2009). Nessa tradição religiosa o feminino é

\footnotetext{
${ }^{12}$ Entrevista com Mãe Raimundinha, sacerdotisa do Terreiro de Mina Nagô de Ogum Elegbade, no dia 30/07/2011.

${ }^{13}$ Entrevista com Mãe Raimundinha, sacerdotisa do Terreiro de Mina Nagô de Ogum Elegbade, no dia 30/07/2011.
} 
interditado devido às regras mensais. E segundo o sacerdote Daniel de Oshalufã:

A mulher sujeita à menstruação é um ser que todo mês fica impura! E não tem jeito! Por isso que na minha casa muitas coisas políticas quem faz sou Eu ou o Léo. Primeiro por causa da hierarquia, e segundo devido à menstruação, que poderia trazer maus fluidos para o jogo de decisão da casa. ${ }^{14}$

Na Mina do Pará, as mulheres menstruadas não podem começar sua feitura de santo na religião e nem participar de rituais críticos de iniciação. Se alguém da hierarquia religiosa lhe perguntar se está menstruada, e se a resposta for positiva, esta deverá imediatamente sair do espaço sagrado. Essa questão pode ser ratificada pela própria pesquisadora:

Em várias observações no interior da Mina Nagô, quando na posição de pesquisadora, fui chamada para observar uma importante feitura de santo ou iniciação no Templo Cristão Afro de Nagô Oxóssi Urucaria em Abaetetuba-PA, antes da entrada no quarto sagrado, local em que a nova mãe de santo estava sendo preparada, o sacerdote Paulo de Oxóssi perguntou, sem meio tom, se estava menstruada, a resposta foi positiva, então Elson de Iansã (já falecido), me convidou a sair daquele espaço sagrado ${ }^{15}$.

Mãe Maria José ao tratar da menstruação afirma que em sua casa, deixa bem claro que:

Uma mulher envolvida por seu fluxo menstrual não pode vir na casa de santo e principalmente no período de obrigações (festas de santo), porque elas

\footnotetext{
${ }^{14}$ Entrevista com Sacerdote Daniel de Oshalufã, zelador do Centro de Manifestações Mediúnicas Oshalufã, no dia 02/07/2011.

${ }^{15}$ Diário de bordo da pesquisadora Lucielma Lobato Silva, dia 20/08/2009.
} 
vão se prejudicar em suas evoluções espirituais. Esse prejuízo é por causa do Exu, que gosta de sangue, $e$ então ele se aproxima com mais força daquela mulher, muitas vezes estas não consegue nem ficar de pé, e o que deveria ajudar a matéria daquela pessoa, a impede de progredir na sua espiritualidade [...] veja a cada obrigação as energias ajudam os médiuns a evoluírem ainda mais [...]. Se ela entra em guma para perder energia é melhor nem aparecer aqui! ${ }^{16}$.

Nessa perspectiva, Augras(1989) demonstra que nas religiões afro-brasileiras acredita-se que tudo o que acontece é devido ao importante fluxo de energia, o qual percorre o mundo inteiro, chamado de axé. O axé é uma força mágico-sagrada que está presente em todos os seres, sejam estes homens/mulheres, animais, objetos e natureza. A intensidade da força do axé pode diminuir ou aumentar, com o tempo vai se desgastando e por isso são necessários os rituais de obrigação que têm a função de recarregar o axé da comunidade. Porém, as transgressões, os tabus e a própria entrada de uma mulher menstruada no espaço sagrado abala negativamente o recarregar das forças do axé. É nesse sentido que o sacerdote Daniel de Oshalufã explica:

Uma mulher menstruada está com uma energia negativa, impura [...] sua força leva o esvaziamento das energias positivas que nós chamamos de axé. É por isso que, eu, ao entrar em contato com uma mulher menstruada, esse estado certamente diminuirá a minha energia, o meu axé, justamente porque ela está em uma fase de perigo, de impureza, carregada de negatividade. Mas a minha energia positiva não vai pra ela. ${ }^{17}$

Essa mesma questão foi levantada na assertiva de Mãe Silvia:

\footnotetext{
${ }^{16}$ Entrevista na Tendo Espírita de Oxum, com a sacerdotisa Mãe Maria José, no dia 29/05/2011.

${ }^{17}$ Entrevista com Sacerdote Daniel de Oshalufã, zelador do Centro de Manifestações Mediúnicas Oshalufã, no dia 02/07/2011.
} 
Uma médium quando visitada (menstruada), não pode vir na casa de santo e se tiver trabalho muito menos!! Ela vai com esse fluxo retirar a força do trabalho e o axé das entidades, as coisas não são as mesmas, tem trabalhos que não dão certo por causa disso. ${ }^{18}$

Dessa forma, a construção sociorreligiosa do tabu na religião Mina Nagô se estabelece como um importante meio de interdição para o gênero feminino, a qual possui poder hierárquico, como mãe de santo, filha de santo ou participante/adepta da religião, mas está sempre presa por seu próprio ser, pois "lidar com mulher é lidar com tabus. É ter que se proteger de incríveis ambiguidades. [...]. A mulher é marginal por si só, já que ela assume, mais claramente do que o homem, a dupla característica de ser humano e animal" (AUGRAS, 1989, p. 40). Então, devido ao próprio corpo feminino e sua fisiologia, a mulher está fadada à servidão da espécie, devido ser poderosa e por isso perigosa, e então não deve ser tocada, não pode entrar em rituais e nem realizá-los, mesmo quando sacerdotisa. Por essa razão, o tabu menstrual é um eficaz mecanismo do gênero masculino para interditar o feminino, inclusive nos espaços onde elas (as mulheres) têm poder hierárquico.

\section{A menstruação: como poder feminino na religião Mina Nagô}

Os tabus ligados à menstruação, para Douglas (2010), estão na categoria de sujeira/perigo, pois podem afetar negativamente a sociedade, e é por essa razão que esta delimita, no seio social, a pessoa passível a tal estado. O universo é dividido entre coisas e ações sujeitas a restrições e outras que não o são; entre as restrições, algumas pretendem proteger a divindade contra a profanação, e

\footnotetext{
${ }^{18}$ Entrevista com Sacerdotisa Mãe Silvia, zeladora do Terreiro da Cabocla Mariana de Mina Nagô, no dia 20/07/2011.
} 


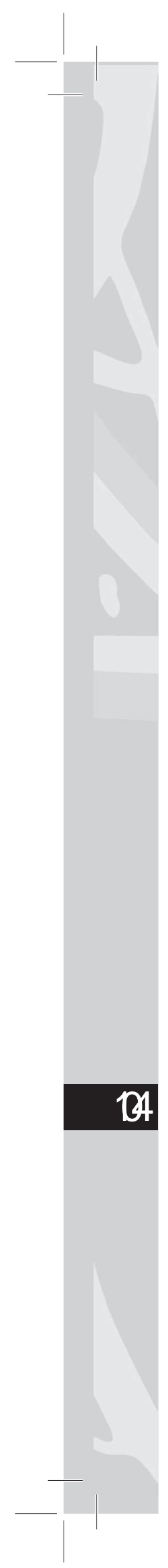

outras, proteger o profano contra a intrusão perigosa da divindade (DOUGLAS, 2010; AUGRAS, 1989). O feminino é visto como causador da desordem, pelo fato de estar propenso à sujeira - o sangue - que abala a ordem.

É nessa perspectiva que Roberto da Matta (1977) aponta o gênero feminino como forte causador da perturbação da ordem social, que, quando menstruada ou de parto, emitem má sorte, justamente por operar em seu corpo algo que não é controlado ou não está nos padrões sociais. Dessa maneira, a mulher transcende a sociedade humana para o desconhecido, para o sujo e para o que está fora da ordem. Sardenberg (1994) menciona que a posição feminina de inferioridade ou subalternidade nas sociedades ocidentais era justificada pelo seu ciclo biológico menstrual que as aproximava da natureza, ou seja, familiarizava a mulher do mundo animal em geral, por isso elas deveriam ser a costela de Adão.

Por outro lado, Bárbara Tedlock (2008), em seu importante livro $A$ mulher no corpo de Xamã, chama atenção ao demonstrar que no xamanismo mexicano, de influência Maia, a mulher tem destaque consideravelmente importante, e justamente devido seu fluxo menstrual, que a torna ainda mais poderosa, mais importante para a realização de suas tarefas ritualísticas, pois o sangue é energia que a possibilita realizar rituais com mais eficácia. "Os hormônios têm papel crucial nas habilidades xamânicas das mulheres, logo, durante o período da menstruação, a mulher exerce com mais vigor seus poderes de cura e de profecia" (TEDLOCK, 2008, p. 177). Segundo esta mesma autora e na mesma obra:

$\mathrm{Na}$ Austrália, entre o povo yolngu, as primeiras menstruações de uma menina são consideradas tão benéficas e poderosas que as mulheres mais velas guardam um pouco de seu sangue para usar mais tarde durante os rituais que marcam a maturidade (TEDLOCK, 2008, p. 183).

No cerne da religião Mina Nagô, esse poder feminino munido da menstruação é visto na fala de Mãe Maria José, que demonstra 
a menstruação como um período em que ela realizava rituais importantíssimos e seu poder redobrava. Em suas próprias palavras:

Mas tem certo ponto que a menstruação pode deixar a pessoa mais poderosa, porque são duas energias ali, a positiva em contato com a negativa que faz com que este médium tenha mais poder, mais força [...] eu já senti [...] um dia eu realmente não tive como parar o trabalho, menstruei e tive que aguentar e até certo ponto em que a entidade não estava encaixada eu estava sentido uma força muito forte, fora do normal, e no momento em que a entidade de cabeça se apoderava e ela, nesse dia, veio com mais força, com mais poder. ${ }^{19}$

Tedlock (2008) afirma que, em diversas sociedades, a menstruação foi vista pelos estudiosos, erroneamente, como tabu restritivo, que deveria ser evitado para não contaminar os que estivessem próximos; e o principal prejudicado seria o homem. Por outro lado, as mulheres xamânicas, quando menstruadas, passavam a ser excluídas, haja vista serem ao mesmo tempo consideradas perigosas e sagradas. Perigosas somente aos outros e não a elas mesmas, uma vez que seu poder emana o sagrado com mais força e poder.

Essa situação na Ceara Lar de Maria de Mãe Mariana é entendida da seguinte maneira:

A menstruação é símbolo da mulher, eu, na minha casa, não tenho contraindicação, mesmo menstruada vou realizar trabalho, tenho uma guia apropriada [...], só não mexo com coisa mais sensivel, mais fina, como fazer a pessoa deitar para o seu anjo de guarda, arriar obrigação [...]. Mas eu posso benzer, dá passe,

\footnotetext{
${ }^{19}$ Entrevista na Tendo Espírita de Oxum, com a sacerdotisa Mãe Maria José, no dia 29/05/2011.
} 
jogar cartas, essas coisas... Mas o fino mesmo eu não posso fazer. ${ }^{20}$

Koss (2004) menciona que o fluir do sangue menstrual tem o efeito de colocar a mulher em uma situação diferenciada no grupo humano, pois é um período que emite poderes mágicos, uma vez que o indivíduo, quando neste estado, encontra-se fora da estrutura social, ligado à natureza, e principalmente à lua, devido à sua mudança de ciclo, o qual emana poder em potencial. De acordo com Mãe Conceição:

\begin{abstract}
A lua tem um papel importante na combinação menstruação e poder, porque quando a menstruação combina com uma lua boa, essa mulher fica poderosa! Cheia de poder, porque é a lua quem the emana mais poder ela, a lua, mexe com tudo, com a maré com os ventos e com a nossa regulação sanguínea. No período de lua cheia sai de perto! A gente fica poderosa! E muito ranzinza. ${ }^{21}$
\end{abstract}

Assim, a menstruação é revestida de poder ao proporcionar ao gênero feminino mais capacidade de lidar com o sagrado. Porém a religião Mina Nagô criou, em seu interior, a forte noção de que este poder é na verdade perigo que deve ser evitado e excluído. Isso se fez devido ser uma religião de característica patriarcal, em que o gênero feminino, apesar de se fazer presente e importante, é seriamente interditada de suas funções políticas e ritualísticas no interior de sua própria casa.

\title{
Algumas considerações
}

$\mathrm{Na}$ religião Mina Nagô, assim como nas demais religiões afro-brasileiras, o gênero feminino se faz presente e com grande

\footnotetext{
${ }^{20}$ Entrevista na Ceara Lar de Maria, com a sacerdotisa Mãe Mariana, no dia 28/07/2011.

${ }^{21}$ Entrevista com Sacerdotisa Mãe Silvia, zeladora do Terreiro da Cabocla Mariana de Mina Nagô, no dia 20/07/2011.
} 
importância. Ele constitui, com o seu sexo oposto, o pilar de sustentação desta religião, ambos se complementam. Porém, à mulher não é reservado todo espaço na organização religiosa, apesar de ela ser a grande mãe, dona do terreiro, mesmo assim é interditada, devido à sua fisiologia, isto é, à menstruação.

O período em que o feminino se encontra em liminaridade não é um estado anterior e nem o seguinte (DOUGLAS, 2010). Assemelham-se ao mundo animal (AUGRAS, 1989) e, devido aos seus ciclos mensais, advindo pela menstruação, torna-se instável e a ponto de explodir, quando não explode (AUAD, 2003), ameaçando então todo o grupo social.

Suárez (1995), em seu artigo intitulado "Enfoques feministas e antropológicos", afirma, nas análises de parentesco de Morgan, que o poder político feminino só foi eficiente em sociedade menos avançadas, pois nas sociedades mais civilizadas o poder passa a ser do masculino, devido à sua capacidade de manter o comando político por muito tempo.

Na esfera do culto Juremeiro, de acordo com Luzuriaga (2001), existem momentos sagrados de grande relevância, como o sacrifício do animal oferecido à entidade, em que a presença feminina é vetada. Mesmo quando a casa é dirigida por uma mulher, esta deve recorrer a um padrinho externo que sempre é convocado especificamente para a realização de certos preceitos. A proibição do acesso feminino às esferas fundamentais do culto, como a musical, em relação aos ilús, e ao sagrado, como o sacrifício, pode ser de certo modo concebida como o veto ao corpo feminino.

Este é um corpo que 'sangra' e, por isso, pode tanto estar numa condição 'impura', diante das entidades, como também de 'abertura' e suscetibilidade a energias que podem ser maléficas para a própria mulher, exigindo assim o seu 'resguardo'. No entanto, as restrições ocorrem independentemente da mulher estar menstruada ou não naquele período, mas pelo fato de ela menstruar. São várias as "configurações socioculturais" ou "ordens prático- simbólicas" em

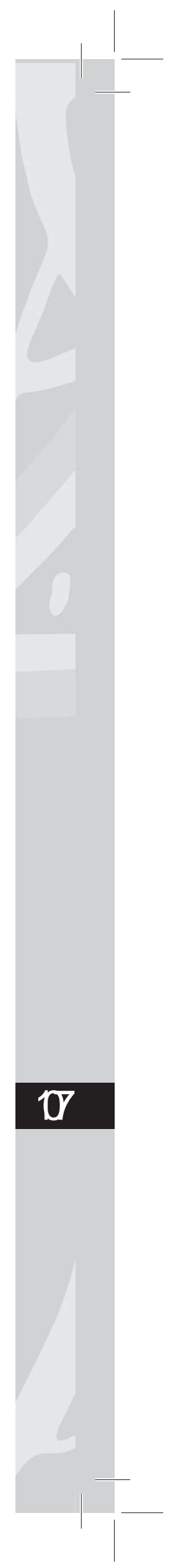


torno da menstruação, assim como são também diferentes as experiências femininas, pois "pode-se afirmar que, embora 'sangrar todo mês' seja destino de toda mulher, a experiência vivida da menstruação será significativamente diferente para mulheres situadas em diferentes contextos históricos, culturais e sociais", caso da jurema (SARDENBERG, 1994, p. 332).

Assim, apenas quando ela 'deixa de ser mulher', ou seja, quando não estiver mais em sua fase reprodutiva, na menopausa, é que pode atuar de forma mais intensa na manipulação do sagrado, o que dificilmente vai acontecer em relação à música, exceto por seu canto.

A questão construída sob o tabu menstrual é muito importante na Mina Nagô, pois, nos interiores das casas de santo, as mulheres são interditadas nas diversas tarefas, e até mesmo de entrar em suas próprias casas, uma vez que:

$$
\begin{aligned}
& \text { quando eu menstruava eu não entrava na minha } \\
& \text { casa, tudo ficava esperando, todos os rituais já eram } \\
& \text { programados para que não coincidissem com a } \\
& \text { menstruação, quando eu era filha de santo eu não ia } \\
& \text { na casa de meu pai. Depois que construir a minha casa } \\
& \text { nela eu também não entro. É respeito pelas minhas } \\
& \text { entidades. }{ }^{22}
\end{aligned}
$$

Dessa forma, o tabu menstrual é um importante elemento de interdição em que o gênero feminino é excluído em todos os sentidos da religião Mina Nagô. E assim todas as decisões políticas e administrativas são promulgadas pelos homens, mesmo em território femininos, pois estes não estão sujeitos ao fluxo e "têm mais capacidade de lidar com política interna do terreiro. Agente não manda muita coisa, eles são quem resolvem essa questão de dinheiro para uma festa de santo, quem

\footnotetext{
${ }^{22}$ Entrevista com Mãe Raimundinha, sacerdotisa do Terreiro de Mina Nagô de Ogum Elegbade, no dia 30/07/2011.
} 
vai ser convidado..."23 Então, a política interna dos espaços sagrados de Mina Nagô não são, em sua maioria, espaços dirigidos por ambos os sexos, pois o tabu menstrual se encarrega de eliminar a mulher de tais questões; mesmo assim ela luta por seu espaço, mas a maioria integrou este tabu e se autointerdita, pelo menos durante o fluxo.

\section{REFERÊNCIAS}

AUAD, Daniele. Feminismo que história é essa? Rio de Janeiro: DP\&A, 2003.

AUGRAS, Monique. O que é tabu? Rio de Janeiro: Coleção Primeiros Passos, 1989.

DA MATTA, Roberto. Panema: uma tentativa de análise estrutural. Ensaios de Antropologia Estrutural. Petrópolis: Vozes, 1977.

DOUGLAS, Mary. Perigo e Pureza. São Paulo: Editora Perspectiva, 2010.

ELIADE, Mircéa. O sagrado e o profano. São Paulo: Martins Fontes, 1992.

FREUD, S. Totem e Tabu e outros trabalhos. Obras Completas. Volume XIII (1913-1914). São Paulo: Imago, 1950.

LUZURIAGA, José Martín Desmaras. Jurema e cura. Dissertação de mestrado em Ciências Sociais. Recife: UFPE, 2001.

MOTTA-MAUÈS, Maria Angélica. "Trabalhadeiras" e "Camarados": relação de gênero, simbolismo e ritualização numa comunidade amazônica. Belém: Centro de Filosofia e Ciências Humanas, 1993.

${ }^{23} \mathrm{Idem}$. 
SARDENBERG, Cecília M. B. "De sangrias, tabus e poderes: a menstruação numa perspectiva sócio-antropológica". Revista Estudos Feministas, v. 2. Florianópolis: UFSC, 1994. p. 314-344.

SEVERINO, A. J. Metodologia do Trabalho Científico. $23^{\mathrm{a}}$ ed, São Paulo: Cortez, 2009.

SILVA, Lucielma Lobato. Mina Nagô do Pará: ainda matriarcado? um estudo dos 28 anos dessa tradição no município de AbaetetubaPA (1980-2008). Trabalho de conclusão de curso. Belém: UFPA, 2009.

SOUZA, Sandra Duarte de. O gênero escrito na literatura evangélica: notas sobre a regulação religiosa do feminino. In: OLIVEIRA, Pedro Ribeiro de; MORI, Geraldo de. Religião e Educação para a Cidadania. São Paulo: Paulinas; Belo Horizonte: SOTER, 2011.

SUÁREZ, Mireya. Enfoques Feministas e Antropologia. Revista Série Antropológica, n. 177, Brasília, 1995.

TEDLOCK, Bárbara. A mulher no corpo de xamã: o feminino na religião e na medicina. Rio de Janeiro: Rooco, 2008

TRIVIÑOS, Augusto Nibaldo Silva. Introdução à pesquisa em ciências sociais: a pesquisa qualitativa em educação. São Paulo: Atlas, 1987.

TURNER, Victor W. O processo ritual. Petrópolis: Ed. Vozes, 1974. p. 116-159. 